NASA/TM-2004-213193

\title{
Thermodynamic Vent System Test in a Low Earth Orbit Simulation
}

Thomas J. VanOverbeke

Glenn Research Center, Cleveland, Ohio 
Since its founding, NASA has been dedicated to the advancement of aeronautics and space science. The NASA Scientific and Technical Information (STI) Program Office plays a key part in helping NASA maintain this important role.

The NASA STI Program Office is operated by Langley Research Center, the Lead Center for NASA's scientific and technical information. The NASA STI Program Office provides access to the NASA STI Database, the largest collection of aeronautical and space science STI in the world. The Program Office is also NASA's institutional mechanism for disseminating the results of its research and development activities. These results are published by NASA in the NASA STI Report Series, which includes the following report types:

- TECHNICAL PUBLICATION. Reports of completed research or a major significant phase of research that present the results of NASA programs and include extensive data or theoretical analysis. Includes compilations of significant scientific and technical data and information deemed to be of continuing reference value. NASA's counterpart of peerreviewed formal professional papers but has less stringent limitations on manuscript length and extent of graphic presentations.

- TECHNICAL MEMORANDUM. Scientific and technical findings that are preliminary or of specialized interest, e.g., quick release reports, working papers, and bibliographies that contain minimal annotation. Does not contain extensive analysis.

- CONTRACTOR REPORT. Scientific and technical findings by NASA-sponsored contractors and grantees.
- CONFERENCE PUBLICATION. Collected papers from scientific and technical conferences, symposia, seminars, or other meetings sponsored or cosponsored by NASA.

- SPECIAL PUBLICATION. Scientific, technical, or historical information from NASA programs, projects, and missions, often concerned with subjects having substantial public interest.

- TECHNICAL TRANSLATION. Englishlanguage translations of foreign scientific and technical material pertinent to NASA's mission.

Specialized services that complement the STI Program Office's diverse offerings include creating custom thesauri, building customized databases, organizing and publishing research results ... even providing videos.

For more information about the NASA STI Program Office, see the following:

- Access the NASA STI Program Home Page at http://www.sti.nasa.gov

- E-mail your question via the Internet to help@sti.nasa.gov

- Fax your question to the NASA Access Help Desk at 301-621-0134

- Telephone the NASA Access Help Desk at 301-621-0390

- Write to:

NASA Access Help Desk

NASA Center for AeroSpace Information 7121 Standard Drive

Hanover, MD 21076 
NASA/TM-2004-213193

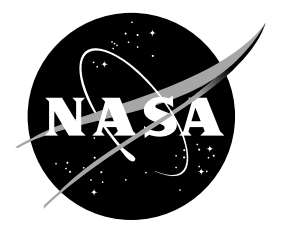

\section{Thermodynamic Vent System Test in a Low Earth Orbit Simulation}

Thomas J. VanOverbeke

Glenn Research Center, Cleveland, Ohio

Prepared for the

40th Joint Propulsion Conference and Exhibit

cosponsored by the AIAA, ASME, SAE, and ASEE

Fort Lauderdale, Florida, July 11-14, 2004

National Aeronautics and

Space Administration

Glenn Research Center 


\section{Acknowledgments}

I wish to give thanks to Brian Blue for designing the TVS heat exchanger, William K. Thompson for designing the controller, and the operations engineers and technicians at SMiRF. They were given a very aggressive schedule and met it.

This report is a formal draft or working paper, intended to solicit comments and ideas from a technical peer group.

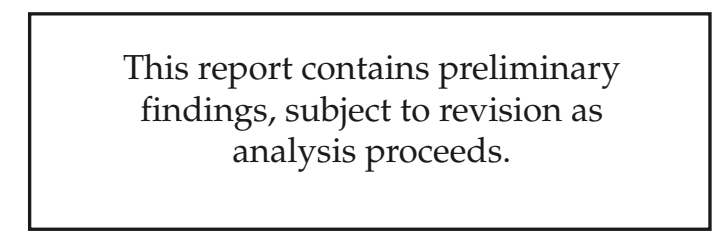

Available from

NASA Center for Aerospace Information 7121 Standard Drive

Hanover, MD 21076
National Technical Information Service 5285 Port Royal Road Springfield, VA 22100 


\title{
Thermodynamic Vent System Test in a Low Earth Orbit Simulation
}

\author{
Thomas J. VanOverbeke \\ National Aeronautics and Space Administration \\ Glenn Research Center \\ Cleveland, Ohio 44135
}

\begin{abstract}
A thermodynamic vent system installed in a cryogenic propellant tank was tested at small multipurpose research facility at NASA Glenn. The test was conducted to simulate the storage of cryogenic oxygen in low earth orbit. There is renewed interest in cryogenic oxygen storage for an advanced second generation Orbital Maneuvering System and Reaction Control Systems in a Low Earth Orbit as Cryogenic propellants are more energetic and environmentally friendly than current storable propellants. Cryogenic storage systems also have an advantage in reduced weight compared to super-critical tanks. Unfortunately, heat transfer or heat leak into these storage systems increases the tank pressure, limiting storage time. On earth, pressure is easily controlled by venting from the ullage space. In 0 -g venting is more complicated as the location of vapor is unknown. Historically upper stages have used auxiliary thrusters to resettle the tank contents and fix the location of the ullage space in orbit. However, this incurs weight penalties and resettling may be required at inopportune times in the mission. An active thermodynamic vent system has been proposed for 0 -g, which consists of a Joule-Thomson valve and heat exchanger coupled with the tank mixer-pump. The combination is used to extract thermal energy from the tank fluid, reducing temperature and ullage pressure. A thermodynamic vent system was designed for this test. Nitrogen was used as the test fluid as it has similar properties to oxygen, but is much safer to work with. The thermodynamic vent system was sized so that the mixer only operated a small fraction of the time. Initially the axial jet mixer used sub-cooled liquid to control pressure. After ullage pressure reached 21 psi and the mixed tank temperature had risen to above 80 Kelvin, fluid was vented. Pressure cycles were performed until cycle characteristics repeated and steady-state operation was demonstrated. Three test runs were conducted at tank fill levels of 97, 80 and $63 \%$ fill. Each test was begun with a boil-off test to determine heat leak into the tank. The 80 and $63 \%$ tank fills had time averaged vent rates very close to steady state boil-off rates. Thus, the thermodynamic vent system was as efficient as the traditional 1-G vent system for lower tank fills and the vent fluid was completely vaporized within the test tank.
\end{abstract}

\section{Introduction}

Heat transfer or heat leak into sub-critical cryogenic containers causes conversion of liquid into vapor which increases tank pressure. Recently a thermodynamic vent system (TVS) to control tank pressure in a large liquid hydrogen tank was tested. ${ }^{1}$ The test had a novel low-gravity spray bar mixing system. The current test uses a smaller flight weight tank filled with nitrogen to simulate cryogenic oxygen storage, and a simpler axial-jet mixer located at the bottom of the tank. The objective of the test was to characterize a simple TVS concept for orbital liquid oxygen storage.

The TVS design incorporated principles of Alban Seigneur's design process for the heat exchanger and the choice of Joule-Thomson valve or pressure orifice. ${ }^{2}$ The system was envisioned to operate intermittently. Continuous operation would add significant motor heating from the mixing pump leading to unnecessary venting. The system would operate between a fixed upper and a lower approximate set point ullage pressure. The mixing pump would be turned on when the tank pressure rose to the upper limit, mixing duration was adjusted depending on how fast tank pressure was reduced. Additional mixing time was used for venting if needed. The decision to vent was based on liquid vapor pressure calculated from bulk liquid temperature. When the calculated saturation pressure of the mixed liquid was above the desired lower pressure set point venting was used. Venting was then used with all subsequent pressure cycles. The total mass vented during a test pressure cycle was controlled depending on the length of the last pressure cycle before venting and measured heat leak into the tank. It was some time before the system reached steady state so minimum cycle pressure varied slightly from the desired value. The time needed to 
perform a steady-state TVS test at a single fill was predicted to be roughly 100-180 hours depending on pressure response, tank fill and heat leak. As multiple tests were to be conducted an automated control system for the TVS was designed to lighten operator work load.

\section{Test Hardware}

This test utilized a flight weight spherical tank. The TVS heat exchanger was designed for slightly more than 200 watts of heat transfer. The Joule-Thomson valve or pressure orifice for this vent flow rate was chosen using equations developed during a cryogenic nitrogen mass flow test. ${ }^{3}$ Spreadsheets were created to size the pressure orifice, determine the vent fluid quality of the throttled nitrogen through the J-T valve, determine the flow rate of the cold nitrogen, and determine the heat transfer in the heat exchanger.

The mixer pump for the test was at the bottom of the tank. A special high efficiency centrifugal cryogenic mixer-pump was built for low head conditions which resulted in a minimum of cryogen heating. ${ }^{4}$ The design condition was $9 \mathrm{gpm}$ at 5.35 feet of head and $2375 \mathrm{rpm}$. Required power at this condition was only about 10 watts. Input power was three phase. The pump was capable of continuous operation from 30 to $110 \%$ of design flow rate at its nominal operating speed.

The TVS used an annular cone shaped heat exchanger design on the pump inlet. The heat exchanger used 8.6 feet of 0.25 " O.D. copper tube placed between the 304 stainless steel shells. A 1/16" clearance is maintained between the stainless steel shells and the copper coil. This ensured minimal pressure drop at the inlet of the mixer. The pump and heat exchanger are shown in Fig. 1. The copper coil is the cool or vent side of the heat exchanger. At the entrance to the copper coil is a Joule-Thomson constriction valve sized for an average vent flow rate of $0.002375 \mathrm{lb} / \mathrm{sec}$. The heat exchanger starts about 4 inches in diameter and ends at 2 inches in diameter. The cooled bulk liquid flows through pump, through the offset tube and is mixed with remaining tank fluid

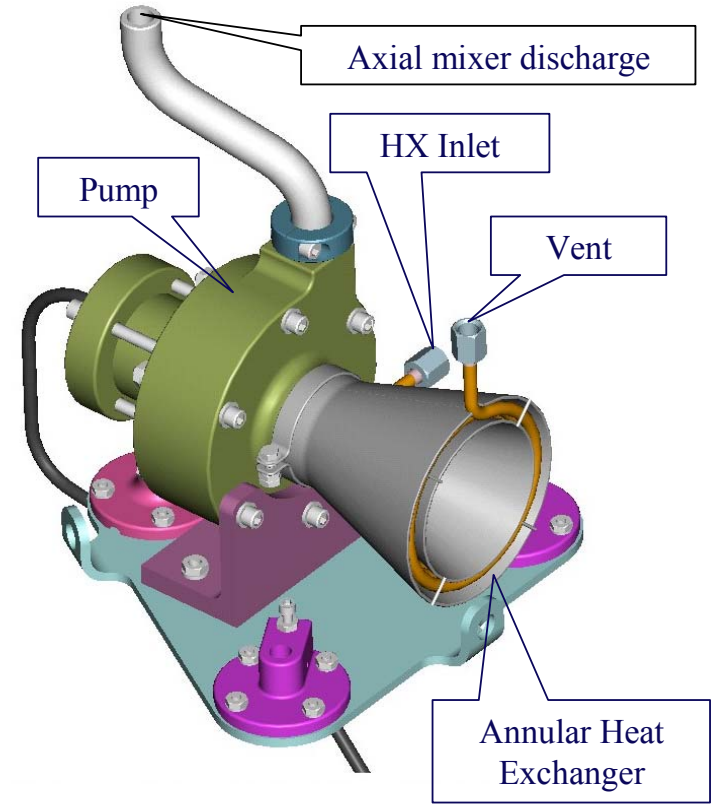

Figure 1.-Centrifugal mixer-pump with heat exchanger.

\section{The Experiment}

The tests were conducted at NASA Glenn Research Center's SMiRF Facility located in the South 40. At GRC, $\mathrm{LN}_{2}$ pressure control tests and an advanced cryo-cooler zero boil-off test were combined. Testing alternated between the two tests. The flight weight tank used was $50 \mathrm{ft}^{3}$ in volume and 54.5 inches high. The complete test assembly is shown in Fig. 2. Equipment from advanced cryo-cooler test was not operated during the TVS tests. The long thermal siphon minimally increased heat leak into the tank. The fin section is between the $60-70 \%$ fill levels. The tank assembly is almost completely surrounded by a cryo-shroud. The cryo-shroud allows simulation of different ambient background temperatures. For this test the cryo-shroud was set at $233 \mathrm{~K}$ or $-40 \mathrm{~F}$. The pump mixer was designed to mount through the top opening and attach to 3 lugs at the bottom of the tank. The TVS vent was connected to the tank lid and required a flexible vent tube as connections were to the tank lid and not through the thin tank walls. The original design was for a copper coiled tube shown in Fig. 2 but the tube proved too stiff and a 6 foot 1/2" ID flexible hose that was available was used. TVS vent flow is regulated by a valve located on the top of the vacuum tank assembly.

Numerous temperature sensors were used in the test. Two sensors were mounted on the fin of the cryo-cooler heat exchanger and a diode temperature rake was mounted to the top cover about 4" off the tank centerline. The tank also had ten wall temperature sensors. The vertical positions of the sensors are listed in table 1 . The sensor name includes a percent fill term after the "-" sign to denote height in the tank. The vertical position of the rake temperatures was accurate to about one inch. Fill level was determined by differential pressure gauge. Tank ullage pressure was measured to an accuracy of $0.05 \mathrm{psi}$. The accuracy of the sensors on the older diode rake was reported to be about one degree Kelvin. 
Table 1.-Temperature sensor height

\begin{tabular}{|l|c|c|c|}
\hline Sensor & $\begin{array}{c}\text { Fill height } \\
\text { (in) }\end{array}$ & $\begin{array}{c}\text { Fill } \\
\text { level } \\
(\%)\end{array}$ & $\begin{array}{c}\text { Error Run } \\
1\end{array}$ \\
\hline L1T-2 & 4.5 & 1.9 & \\
\hline L2T-2 & 4.5 & 1.9 & \\
\hline L3T-51 & 27.5 & 50.66 & 2.25 low \\
\hline L4T-60 & 31.0 & 60.23 & 2.25 low \\
\hline L5T-80 & 39.0 & 80.32 & 2.0 low \\
\hline L8T-91 & 44.5 & 91.13 & 2.0 low \\
\hline L9T-95 & 47.5 & 95.47 & $0.7-8$ low \\
\hline L10T-95 & 47.5 & 95.47 & $0.7-8$ low \\
\hline SD1-2 & 4.6 & 2 & 0.1 high \\
\hline SD2-2 & 4.6 & 2 & 0.25 low \\
\hline SD3-25 & 17.8 & 25 & 0.4 low \\
\hline SD4-25 & 17.8 & 25 & 0.1 low \\
\hline SD5-50 & 27.25 & 50 & 0.15 low \\
\hline SD6-50 & 27.25 & 50 & 0.3 low \\
\hline SD7-75 & 36.7 & 75 & \\
\hline SD8-75 & 36.7 & 75 & \\
\hline SD9-95 & 47.1 & 95 & 1.0 high \\
\hline SD10-95 & 47.1 & 95 & 4.0 high \\
\hline SD11 & & $60-70$ & \\
\hline SD12 & & $60-70$ & \\
\hline
\end{tabular}



Figure 2.-Test Assembly

\section{Results and Discussion}

All tests operated between 19.0 and 21.0 psia. The pump was operated at $36 \%$ power as this power level was found to be adequate in a checkout test. Due to limited test time and equipment reliability, the boil-off tests were terminated after approximately 12 hours when manual checking of vent flow meters indicated approximately steady reading.

\section{A. Test Run 1}

The tank was filled to approximately 97-98\% full. Ullage pressure and fin temperature from test run 1 are shown in Fig. 3. The average of fin temperatures (SD11 and SD12) was used for bulk liquid temperature and to decide whether to vent or not. Fin temperature rose with pressure to reach a temperature of about $80.2 \mathrm{~K}$ during the 60 hour test.

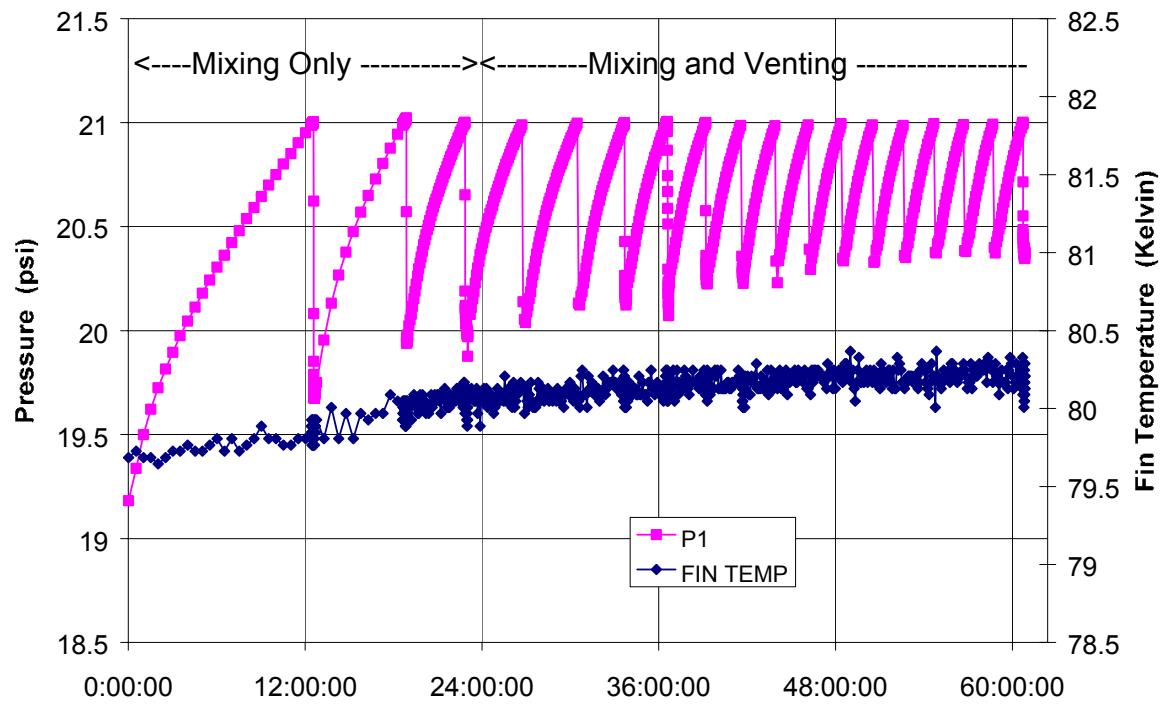

Elapsed Time

Figure 3.-Ullage pressure and fin temperature for test 1. 
During the third mixing cycle TVS venting was used to limit the rise in calculated saturation pressure. By the 16th cycle vent minimum pressure has stabilized at 20.35 psia, as shown in Fig. 4. This was the last vent for the first test. It was desired to end vent cycles at 20.0 psi to better compare data between the test runs. Thus, a somewhat larger vent flow would have been needed to reach the target pressure. This would decrease the minimum cycle pressure and increase cycle time. There are several different steps or phases in the pressure reduction cycle. First, tank pressure in Fig. 4 drops over 0.5 psi due to mixing of tank contents before any fluid is vented. Mixing the subcooled liquid gives substantial pressure reduction in a short period of time. In the second phase the vent valve above the tank is opened and fluid is vented. Vent flow at or near the beginning of a vent cycle is larger than the design intent because liquid seeps into the heat exchanger and TVS vent line between

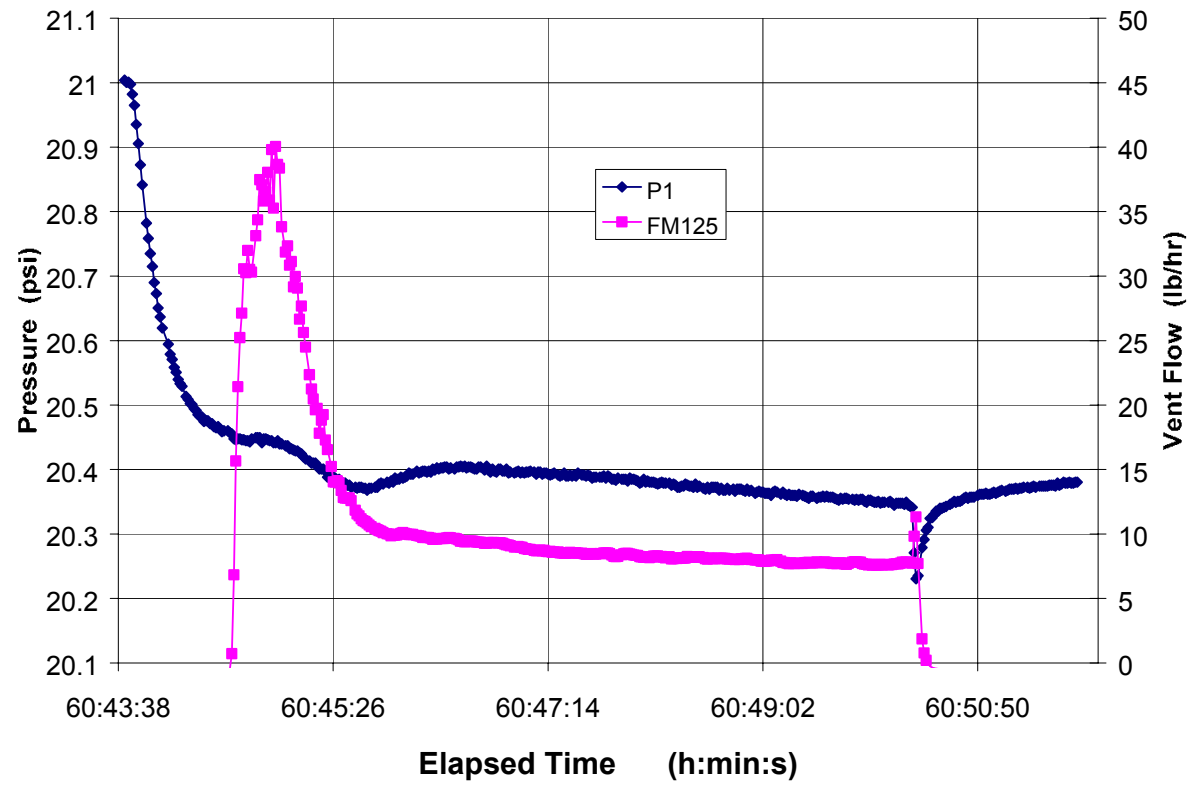

Figure 4.-Pressure and vent flow from last vent cycle, run 1.

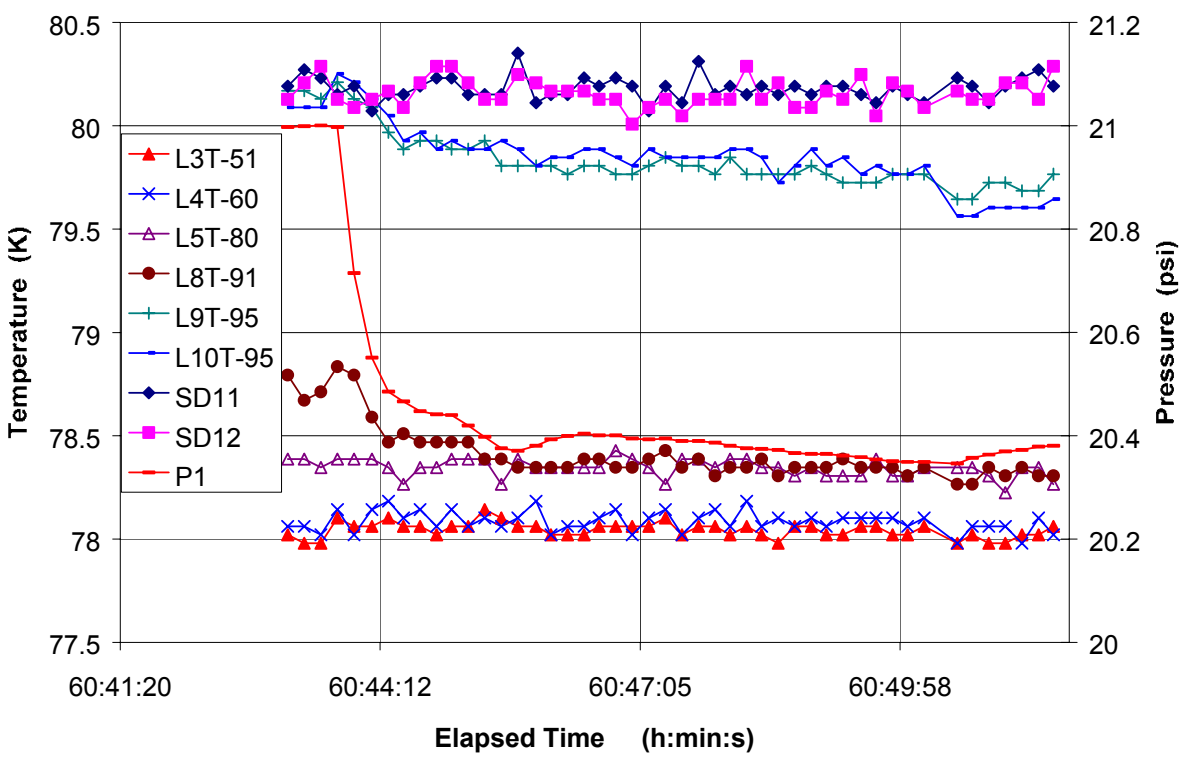

Figure 5.-Ullage pressure, rake and fin temperatures during the last vent cycle of the first test. 


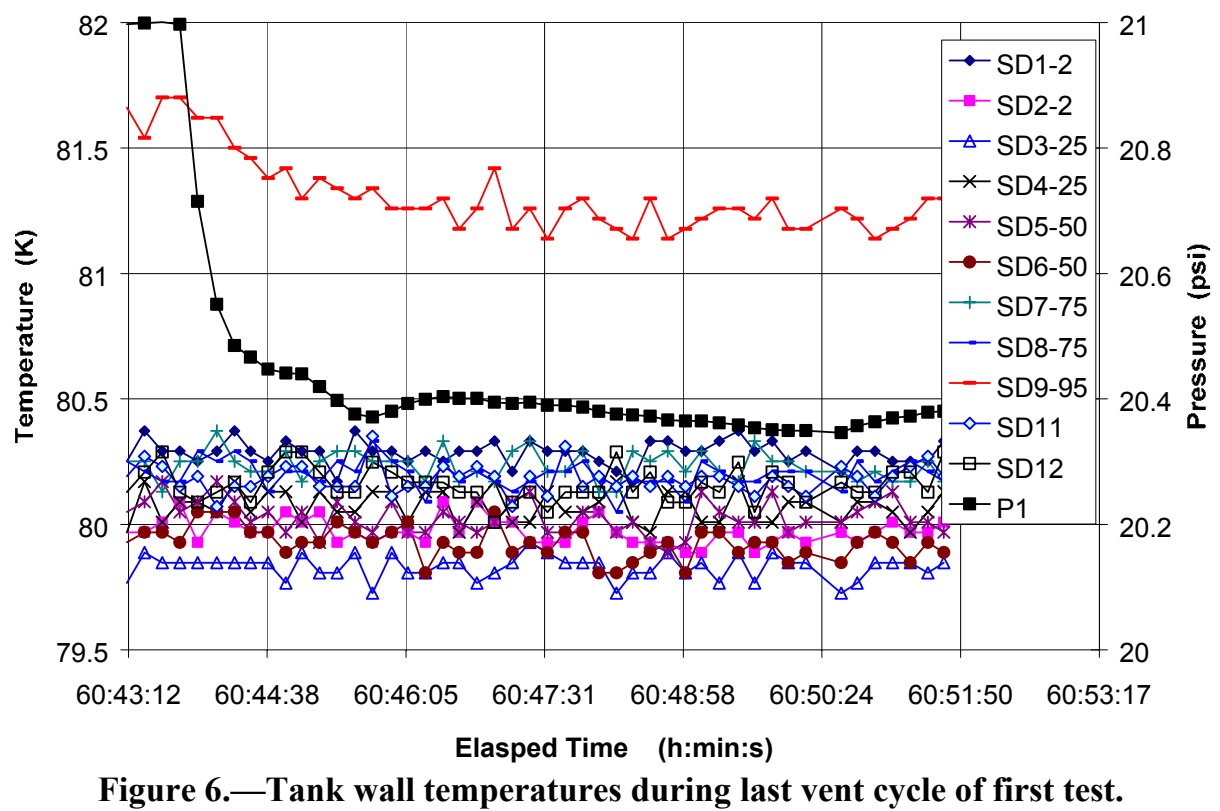

cycles. The Joule-Thomson valve or pressure orifice limits flow into the heat exchanger but it does not stop it. The increased vent flow rate causes ullage pressure to initially drop at a higher rate. After vent flow decreases ullage pressure momentarily increases. The temporary increase in vent rate increased heat transfer and probably causes lower temperatures throughout the heat exchanger and at the liquid-vapor interface. This leads to increased condensation and ullage pressure drop during peak venting. The vent rate data was integrated and it was determined that an average of $0.1 \mathrm{~kg}$ is vented above design flow rates in the vent spike. After the vent rate slows, the heat transfer through the TVS also slows and it is inferred that as the temperature difference across the heat exchanger lessens, heat exchanger exit temperature rises along with liquid-vapor interface temperature during the momentary pressure rise during this phase in Fig. 4. Continued venting reduces ullage pressure. During the latter half of the vent cycle, the vent rate is essentially constant and pressure drops at a nearly constant rate.

The time averaged TVS vent rate was above the boil-off rate determined earlier. Thus, there was the possibility of liquid passing out of the tank. If the vent fluid is not completely vaporized inside the tank, the cooling effect of the phase change is lost for the remaining tank fluid. Venting liquid outside the tank is wasteful and does not reduce tank pressure. Venting liquid may have happened during the vent spike.

The vent flow is shut off at the end of a vent cycle by closing a vent valve located above the tank assembly. At this point there is almost a 5 psi pressure difference across the TVS. Flow continues into the TVS until pressure equalizes. In an attempt to limit flow into the TVS after a vent cycle, some pressure was bled off the ullage into the closed off TVS vent line. This is why the pressure drops at the end of the vent cycle in Fig. 4. Unfortunately this did not stop liquid from seeping into the TVS because the vent spike remained in subsequent vent cycles and this practice was not employed after the first test run.

Temperatures for the last vent of the first run are shown in Figs. 5 and 6. Pressure data is repeated from Fig. 4 to show how temperature changes during the mixing and venting phases. Pressure and upper tank temperatures decrease rapidly at the beginning of the pressure reduction cycle prior to venting. Rake temperatures from the higher fill levels (L8T-91, L9T-95 and L10T-95) decrease about half a degree during the pressure reduction.

Lower tank sensors show a much smaller decrease in temperature. The minimum cycle pressure is 20.34 psia which corresponds to a saturation temperature of $80.24 \mathrm{~K}$. Liquid temperatures should be relatively close to this value at the end of a mixing-vent cycle, as fin temperature sensors, SD11 and SD12 are. Most of the tank wall temperatures shown in Fig. 6 are within $0.4 \mathrm{~K}$. Errors in the temperature sensors are tabulated in table 1 for the first test run.

\section{B. Test Run 2}

For the second run the tank was emptied to the $80 \%$ fill level. The run was begun with a boil-off test at 19 psia. This took about 12 hours and the boil-off rate was approximately 9.2 watts. This was almost half a watt higher than test run 1. It was expected that boil-off rates would be closer and, with increased ullage space, the pressure rise rate 
would be slightly lower. Although during the test it appeared that steady-state had been attained, more time should have been allowed for reaching steady-state

Figure 7 shows ullage pressure and fin temperature during the second run. Fin temperature is seen to rise and fall with pressure each cycle. While test 1 displayed a general rise with pressure during the first few cycles, test 2 shows stronger coupling between fin temperature and ullage pressure during each pressure cycle. There is still some variability in temperature measurements. The temperature variability range is almost half the cycle temperature change. Thus, SD11 and SD12 temperature measurements were used for control or ending vents, this would cause some cycle to cycle variability. As pressure can be measured more accurately here, use of minimum cycle pressure to terminate venting would make this variability much smaller.

The ullage volume was much larger for run 2 and the pressure cycle time was correspondingly longer. It took almost 24 hours for the first pressure cycle. At that time the fin temperature was above 80.07 Kelvin after mixing so venting was employed. $0.7 \mathrm{Kg}$ was vented the first cycle. Due to an error, the mixing pump ran from first venting to the second venting. Surprisingly this did not double the pressure rise rate as the pump was only using 3.5 watts, which was less than expected. Later, $1.0 \mathrm{Kg}$ was vented which dropped the ullage pressure from about 21.1 to 20.8 psia. The pressure rise after the second vent was very rapid and a short time later the pressure rose to 21.0 psi and the third vent cycle was initiated by the controller for a $2.0 \mathrm{~kg}$ vent. What appears to be a single jagged vent cycle just before the thirty-sixth hour in Fig. 7 was actually two separate cycles. The third vent dropped the ullage pressure to 20.1 psia. During the eighth and last vent cycle pressure drops to 19.8 psia. Pressure and vent flow from the last vent cycle of run 2 is shown in Fig. 8. The vent mass should have been smaller to have a minimum pressure of 20.0 psi. A vent spike is shown at the beginning of venting. Pressure rises almost $0.1 \mathrm{psi}$ at the end of the spike, a little larger than for the first test. At larger tank fills, the cooling flow from the mixer/heat exchanger is more thoroughly mixed with bulk tank fluid by the time it reaches the liquid-vapor interface. With lower tank fills the interface temperature is cooled more during vent spikes. As in the first test, $0.1 \mathrm{~kg}$ was determined to have seeped into the TVS and vent line between vents by integrating data in a spreadsheet. Looking at Fig. 8, the vent spike initially looks much smaller than in the first test run until the much longer cycle time is taken into account. The vent mass is four times as large and each vent cycle takes about 40 minutes. Pressure decreases about 0.6 psi during mixing and the initial high vent rate. Pressure drops another 0.6 psi during the rest of the vent cycle.

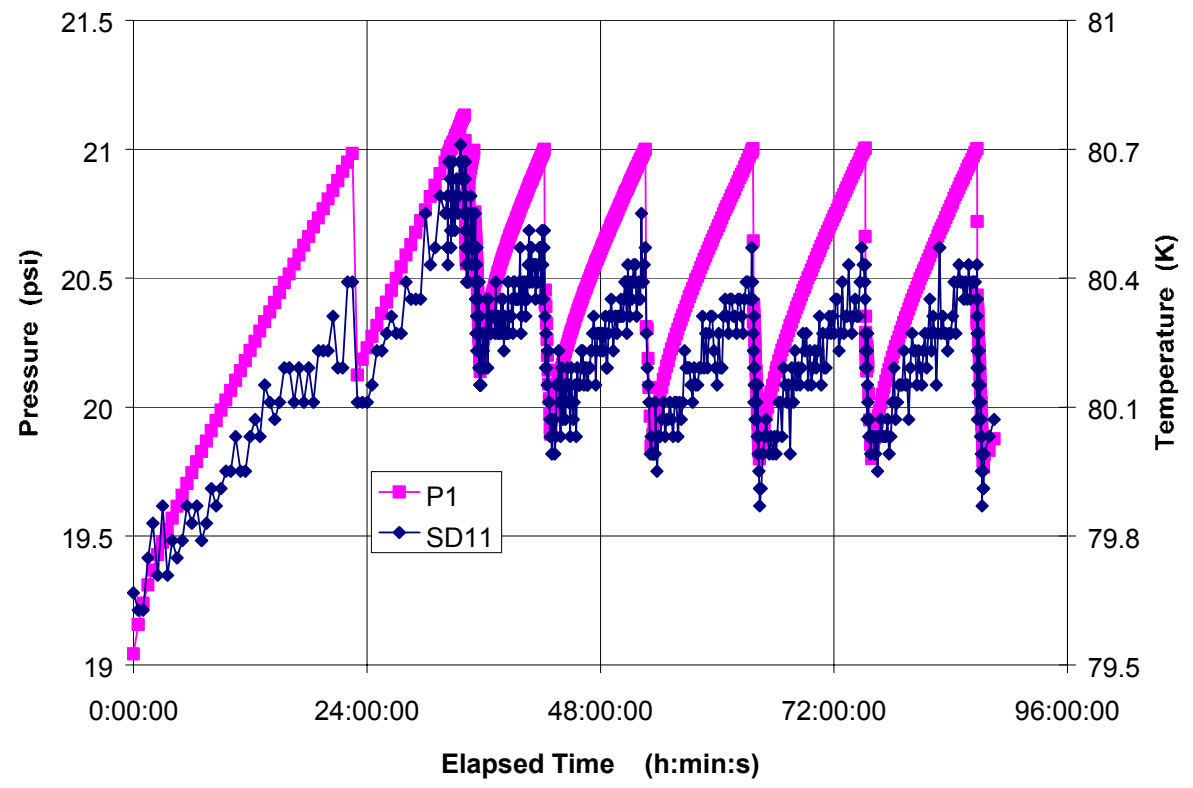

Figure 7.-Ullage pressure and fin temperature during run 2. 
Rake and fin temperatures during the last vent for run 2 are shown in Fig. 9. Initial temperature reduction is rapid. Temperatures in the liquid decrease less than half a degree during the vent, which agrees with temperature increase during pressure build-up. Ullage temperatures decrease about $0.8 \mathrm{~K}$, about half during initial mixing and half during the long vent process. This corresponds to the ullage pressure decrease. Temperature increases are seen after the vent spike in the ullage sensors L8T-91, L9T-95 and L10T-95. The data for L5T-80 during the same period is inconclusive. SD11 and SD12 don't show a temperature increase after the vent spike but these sensors are measuring an average of the fin and liquid temperatures and showed remarkably small change throughout the test runs. The fin must temper temperature change over itself in the liquid between the 60 and $70 \%$ fills. Wall temperatures for this vent are shown in Fig. 10. SD9-95, SD7-75 and SD8-75 decrease around 0.6 K during the pressure reduction. Wall temperatures in the ullage decrease a little slower than rake temperatures, probably due to the heat capacity of the metal tank wall.

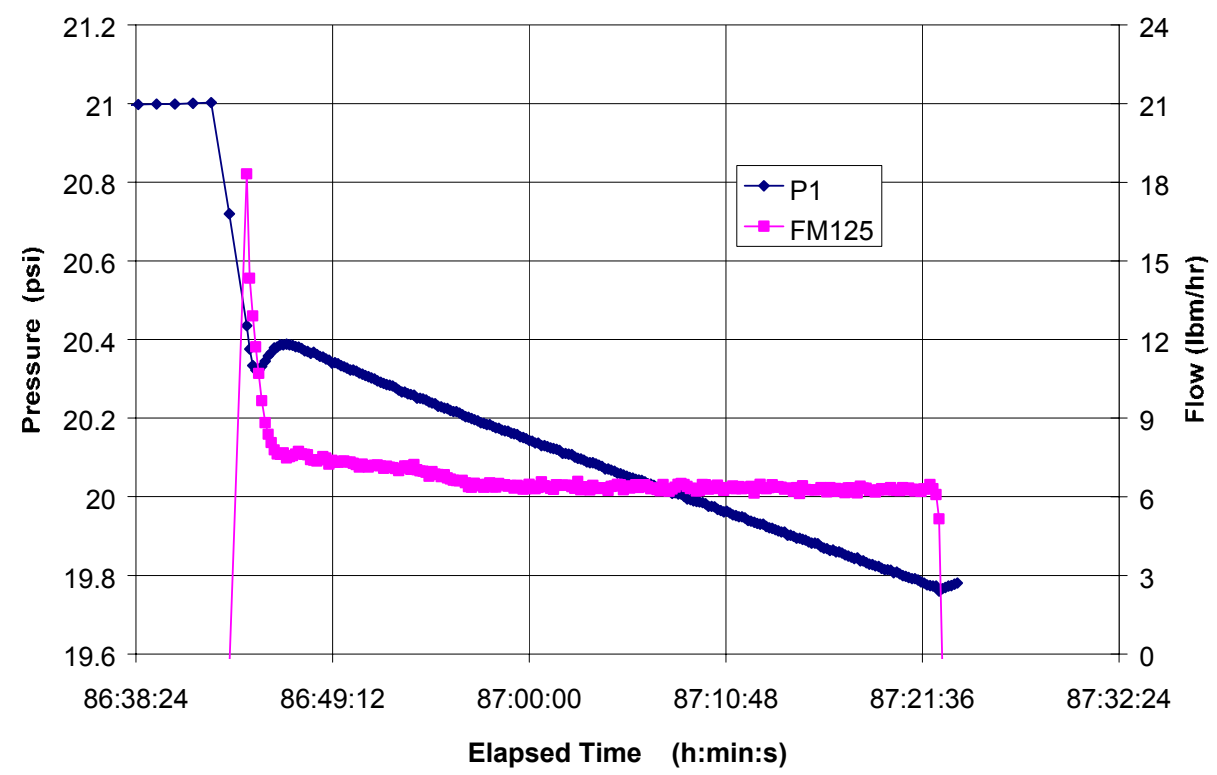

Figure 8. - Ullage pressure and vent flow during the last vent, test 2.

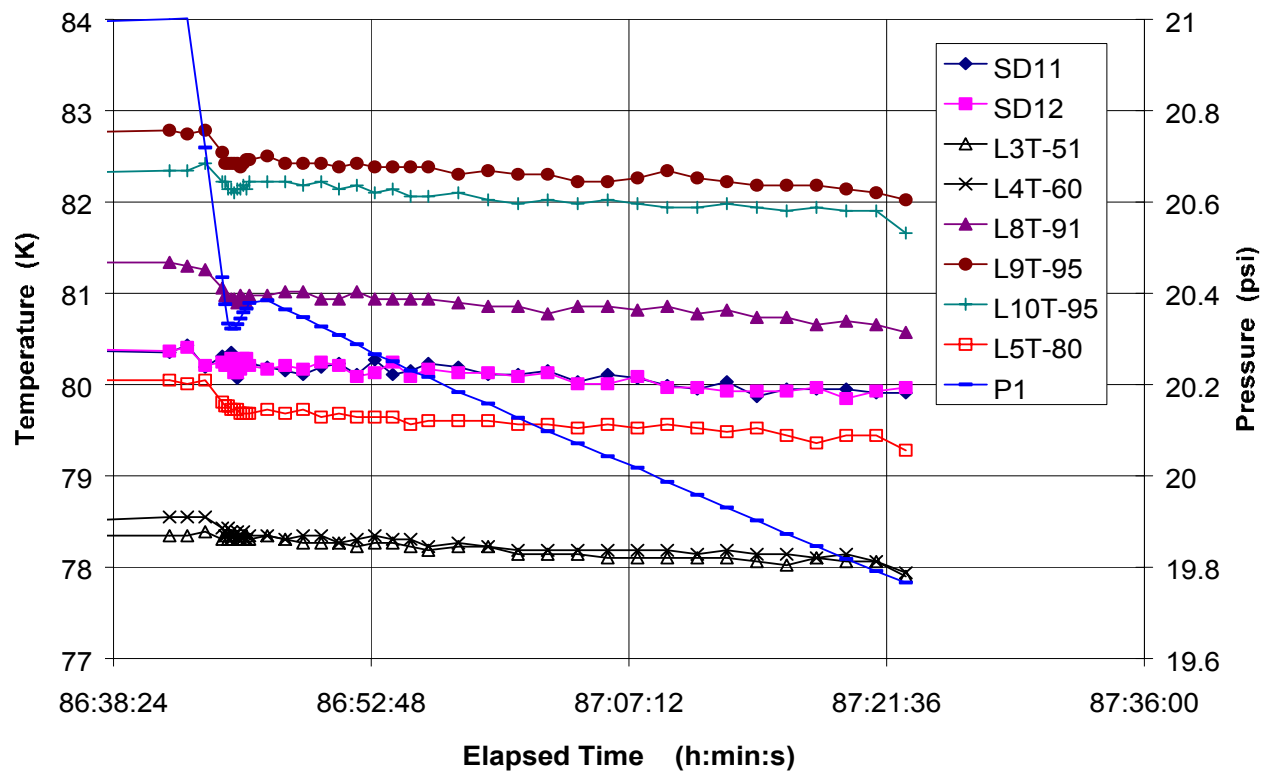

Figure 9.-Liquid temperatures during the last vent, run 2. 


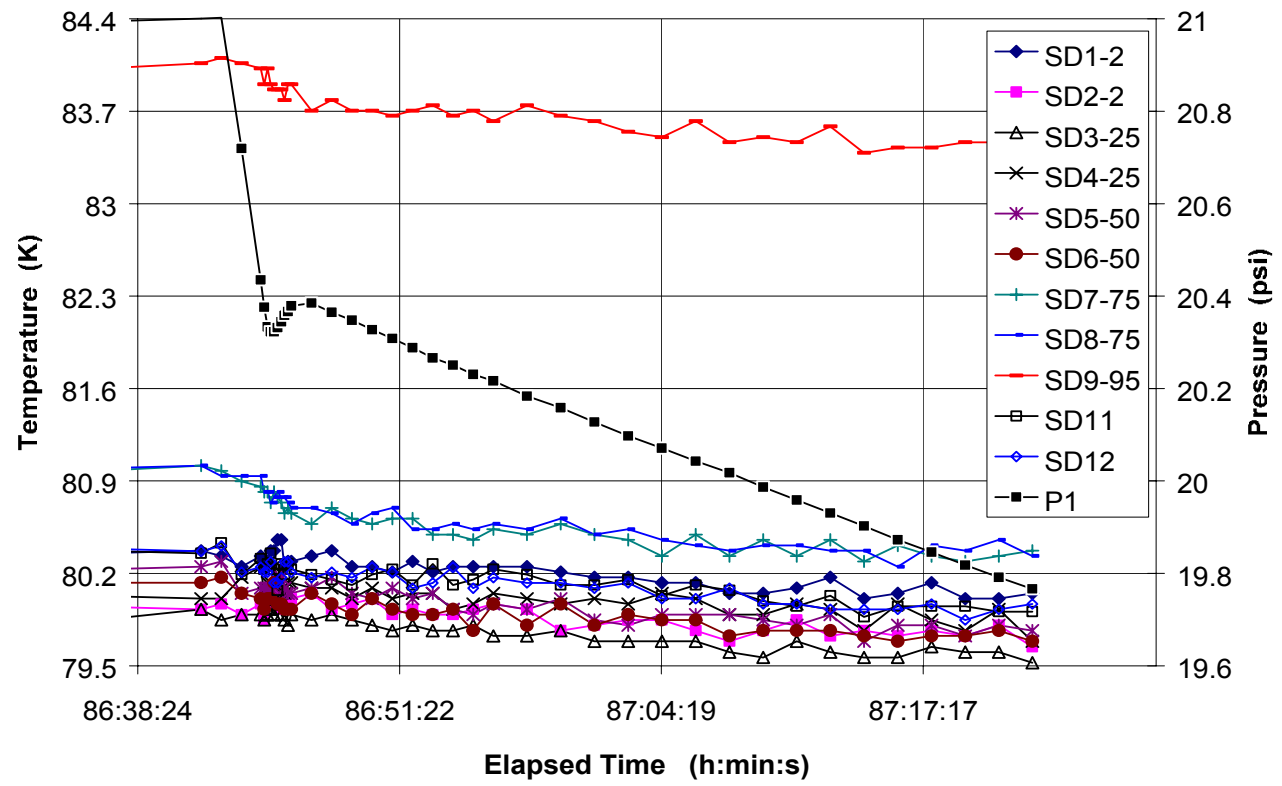

Figure 10.-Wall and fin temperatures during the last vent, run 2.

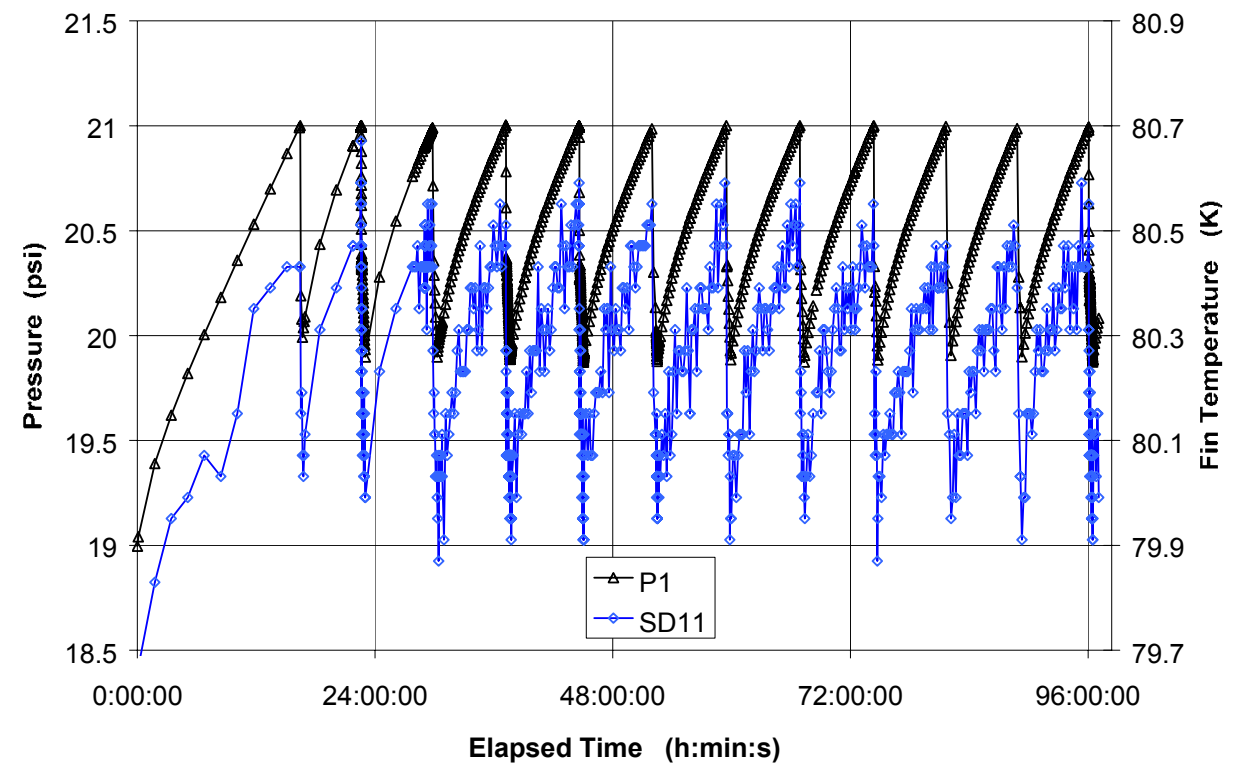

Figure 11.-Ullage pressure and fin temperature during run 3.

\section{Test Run 3}

For test run 3 the tank was emptied to $63 \%$ fill, which kept the fin partially in the liquid. The fin was 6 inches high. The semi-pointed end of the thermal siphon extends another inch. Thus, the fin ranges from $60-70 \%$ fill levels of the tank. Pressure and fin temperature for test 3 is shown in Fig. 11. As can be seen from the figure, ullage pressure and liquid-vapor interface temperature are very strongly coupled. Fin temperature increased about $1.0 \mathrm{~K}$ during test 3 . This agrees with saturation temperature change for a pressure increase of 2 psi. Fin temperature shows discrete variations that are particularly noticeable when the data record rate is increased. Total time of the test run was about 96 hours and pressure cycles were roughly 7.24 hours long.

Pressure and vent flow for the last vent is shown in Fig. 12. Approximately half the cycle pressure reduction is obtained by mixing sub-cooled liquid. The vent rate takes a little longer to build up than seen previously and peak 
venting occurs later in the cycle. Final pressure after the vent is slightly less than 19.9 psia. $1.3 \mathrm{Kg}$ is vented in a little more than 20 minutes. As shown previously, pressure drops during the vent spike and rises after the end of the vent spike. Ullage pressure rises above what it was before the vent spike when venting was at design rates. It is possible that the vent spike caused a change in mixing/cooling at the liquid-vapor interface.

Temperatures during the last vent cycle are shown in Figs. 13 and 14. SD11, SD12, SD5-50 and SD6-50 show the quickest temperature drop in the first two minutes. Ullage temperatures, L5T-80, L8T-91 and L9T-95 indicate small temperature increases just after the vent spike ends and pressure rises. In Fig. 14, ullage wall temperatures don't show an increase during the transient pressure rise after the vent rate drops. Initially, ullage wall temperatures drop at a slower rate than ullage rake temperatures indicating that the heat capacity of the metal tank slows temperature change.

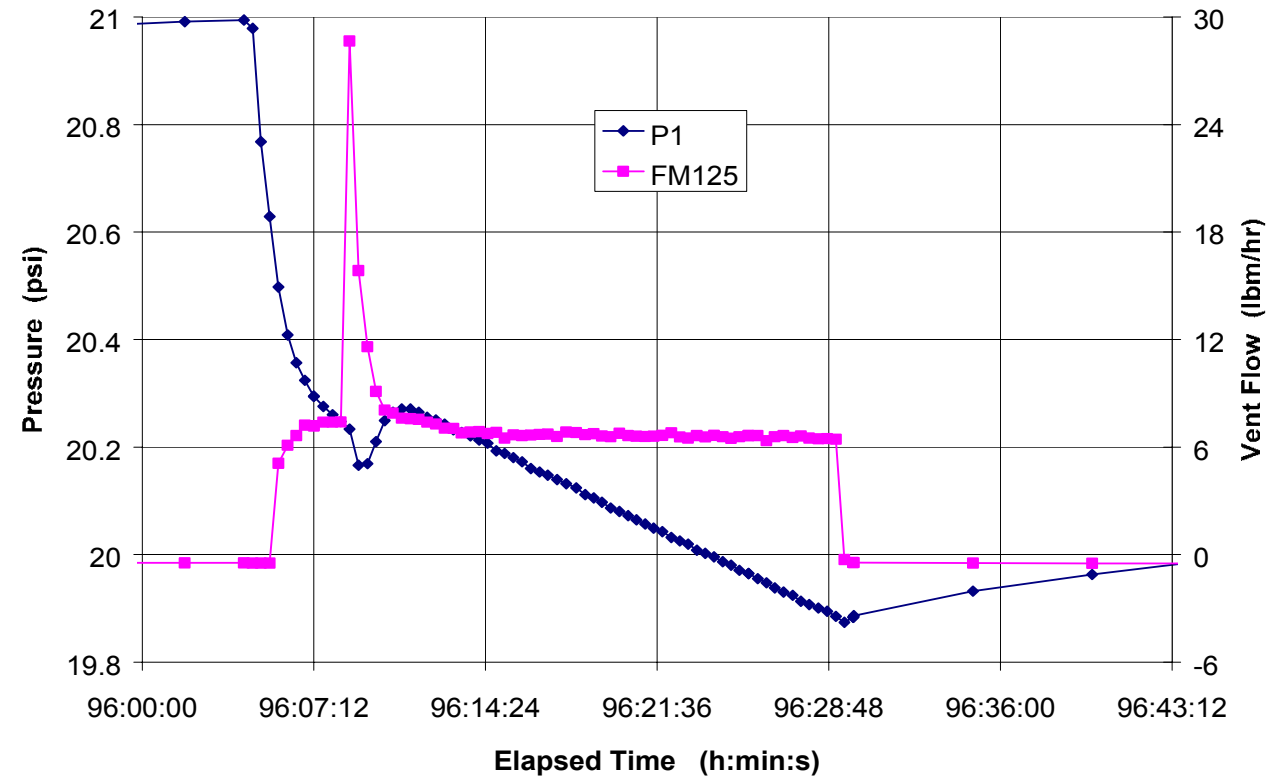

Figure 12.- Ullage pressure and vent flow during last vent, run 3.

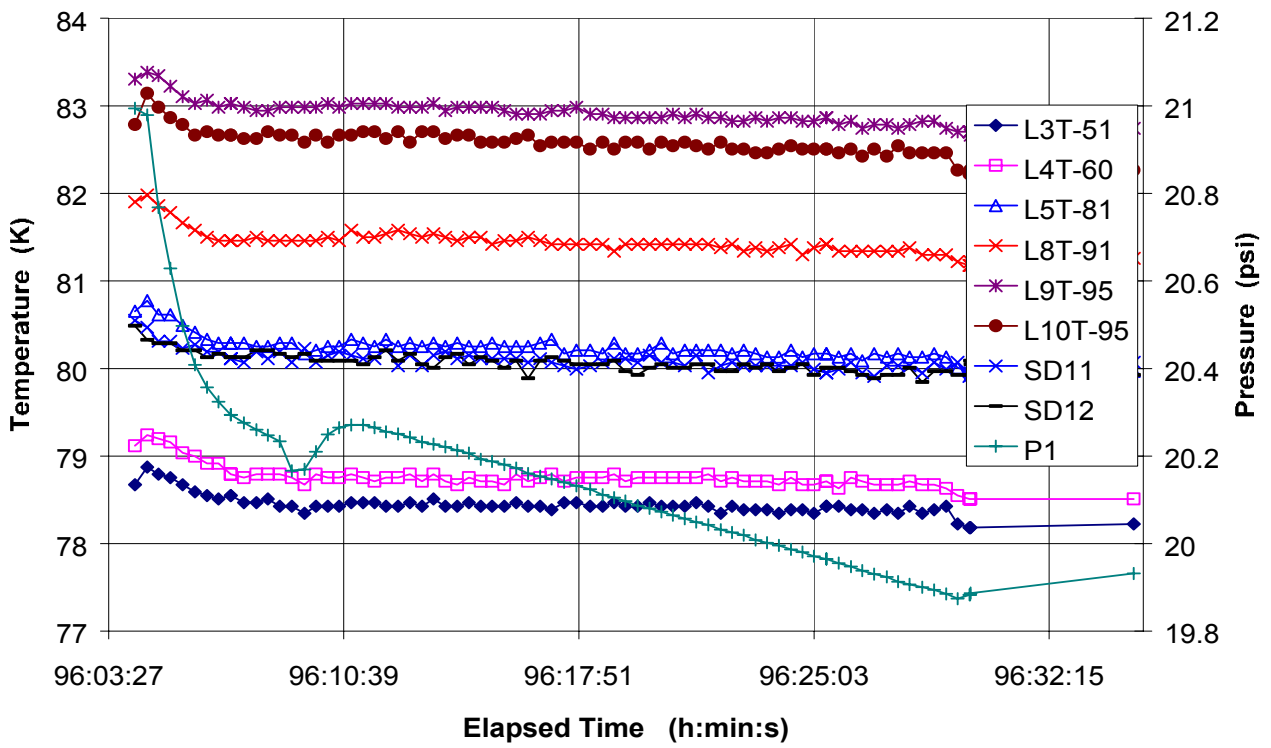

Figure 13.- Rake and fin temperatures during the last vent, run 3. 




Figure 14.-Wall temperatures during last vent, run 3.

Table 2.-Time averaged TVS vent rate compared to boil-off rate.

\begin{tabular}{|c|c|c|c|c|c|}
\hline Test & $\begin{array}{c}\text { Vent } \\
\text { Mass }\end{array}$ & $\begin{array}{c}\text { Cycle } \\
\text { Length }\end{array}$ & Average & Boil-off rate & Efficiency \\
\hline 1 & $0.5 \mathrm{Kg}$ & 2.04 hours & $0.245 \mathrm{~kg} / \mathrm{hr}$ & $.16395 \mathrm{~kg} / \mathrm{hr}$ & 0.67 \\
\hline 2 & $2.0 \mathrm{Kg}$ & 11.5 hours & $0.174 \mathrm{~kg} / \mathrm{hr}$ & $.1726 \mathrm{~kg} / \mathrm{hr}$ & 0.99 \\
\hline 3 & $1.3 \mathrm{Kg}$ & 7.24 hours & $0.180 \mathrm{~kg} / \mathrm{hr}$ & $.17636 \mathrm{~kg} / \mathrm{hr}$ & 1.00 \\
\hline
\end{tabular}

\section{Summary}

Time averaged vent rates are shown in table 2 compared to boil-off rate. TVS efficiency is defined as boil-off rate divided by time averaged TVS vent rate. The first run had an efficiency of 0.67 . At first it was thought that the seepage into vent line was a large source of inefficiency or the heat exchanger was undersized and liquid was boiling outside of the heat exchanger. However, the second and third runs did not show this inefficiency. The first test run had the highest minimum cycle pressure, at 20.34 psia, which was governed by the vent mass. The other two test runs had minimum cycle pressures of 19.76 and 19.89 at steady state. The first run had very short pressure cycles. With short heating time, most of the ullage pressure reduction was achieved by initial tank mixing. The second and third runs had much longer cycle times and vents accounted for a larger fraction of ullage pressure control.

\section{Concluding Remarks}

Three successful pressure control runs were conducted using an active thermodynamic vent system in a nitrogen storage tank in simulated low earth orbit environment. The TVS and mixer operated successfully keeping pressure under control for three different tank fills. When the mixer was turned on, substantial initial pressure reduction was obtained by mixing the thermally stratified warmer fluid at the top of the tank with colder fluid from the bottom of the tank. This cooled the liquid-vapor interface promoting condensation and pressure reduction. The TVS was inefficient at very high tank fill. The reason for this was not found. For the two lower fills the system operated very efficiently. The mixer contributed very little to tank warming by operating as little as possible and at low power.

The vent valve controlling the TVS was located outside of the tank. This led to a small amount of liquid seeping into the heat exchanger and vent tube between cycles causing a temporary increase in vent rate significantly above design rates. Pressure was reduced at a faster rate during increased vent rate but pressure temporarily rose afterwards. 
In this series of tests the vent cycle was terminated based on the mass vented. Bulk temperature could also have been used for vent control. However, test temperature sensors displayed significant variation. Using minimum set pressure to terminate venting would probably be the best control method. This would allow better comparisons between test runs.

\section{References}

${ }^{1}$ Hastings, L.J., Flachbart, R.H., Martin, J.J., Hedayat, A., Fazah, M., Lak, T., Nguyen, H., and Bailey, J.W. "Spray Bar Zero-Gravity Vent System for On-Orbit Liquid Hydrogen,” NASA/TM-2003-212926, Oct. 2003.

${ }^{2}$ Seigneur, A.D., "Design, Analysis, Fabrication, and Testing of an Active Heat Exchanger for Use in Cryogenic Fluids," Master's Thesis, Cleveland State University, March, 1994.

${ }^{3}$ Papell, S.S., Saiyed, N.H., and Nyland, T.W., "Acquisition and Correlation of Cryogenic Nitrogen Mass Flow Data Through a Multiple Orifice Joule-Thomson Device,” NASA/TM-1990-103121, May 1990.

${ }^{4}$ Barber-Nichols Inc., "Zin Technologies Liquid Nitrogen Pump BNP-25-000 Installation, Operating and Maintenance Manual," Zin Technologies, 3000 Aerospace Parkway, Brook Park, Ohio, February 2002. 


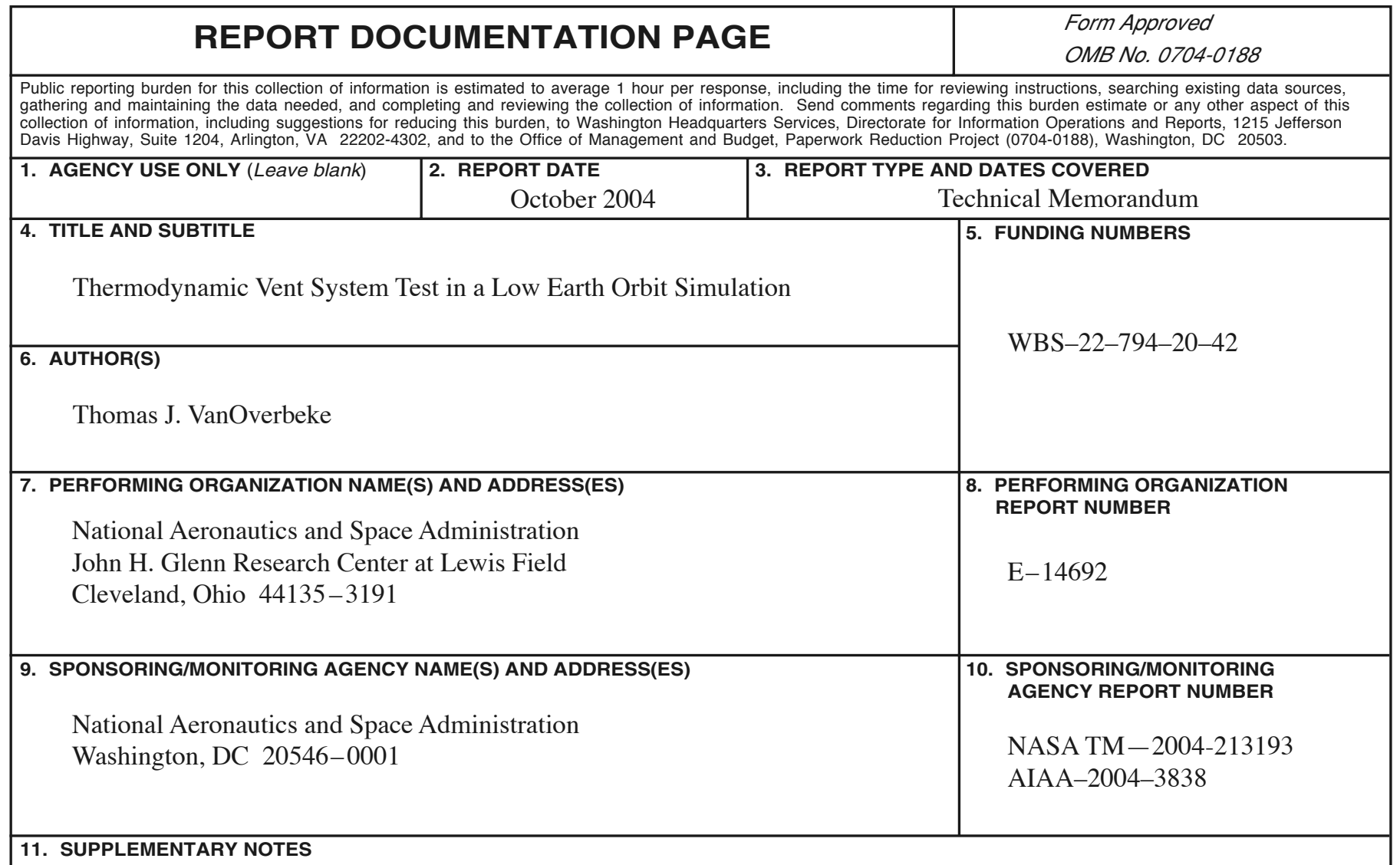

Prepared for the 40th Joint Propulsion Conference and Exhibit cosponsored by the AIAA, ASME, SAE, and ASEE, Fort Lauderdale, Florida, July 11-14, 2004. Responsible person, Thomas J. VanOverbeke, organization code 5870, 216-433-5867.

12a. DISTRIBUTION/AVAILABILITY STATEMENT 12b. DISTRIBUTION CODE

Unclassified - Unlimited

Subject Category: 01

Distribution: Nonstandard

Available electronically at http://gltrs.grc.nasa.gov

This publication is available from the NASA Center for AeroSpace Information, 301-621-0390.

13. ABSTRACT (Maximum 200 words)

A thermodynamic vent system for a cryogenic nitrogen tank was tested in a vacuum chamber simulating oxygen storage in low earth orbit. The nitrogen tank was surrounded by a cryo-shroud at $-40^{\circ} \mathrm{F}$. The tank was insulated with two layers of multi-layer insulation. Heat transfer into cryogenic tanks causes phase change and increases tank pressure which must be controlled. A thermodynamic vent system was used to control pressure as the location of vapor is unknown in low gravity and direct venting would be wasteful. The thermodynamic vent system consists of a Joule-Thomson valve and heat exchanger installed on the inlet side of the tank mixer-pump. The combination is used to extract thermal energy from the tank fluid, reducing temperature and ullage pressure. The system was sized so that the tank mixer-pump operated a small fraction of the time to limit motor heating. Initially the mixer used sub-cooled liquid to cool the liquid-vapor interface inducing condensation and pressure reduction. Later, the thermodynamic vent system was used. Pressure cycles were performed until steady-state operation was demonstrated. Three test runs were conducted at tank fills of 97, 80, and 63 percent. Each test was begun with a boil-off test to determine heat transfer into the tank. The lower tank fills had time averaged vent rates very close to steady-state boil-off rates showing the thermodynamic vent system was nearly as efficient as direct venting in normal gravity.

\begin{tabular}{|c|c|c|}
\hline \multicolumn{3}{|l|}{$\begin{array}{l}\text { Venting; Thermodynamic } \\
\text { Shrouds; Evaporation }\end{array}$} \\
\hline $\begin{array}{l}\text { 17. SECURITY CLASSIFICATION } \\
\text { OF REPORT }\end{array}$ & $\begin{array}{l}\text { 18. SECURITY CLASSIFICATION } \\
\text { OF THIS PAGE }\end{array}$ & $\begin{array}{l}\text { 19. SECURITY CLASSIFICATION } \\
\text { OF ABSTRACT }\end{array}$ \\
\hline Unclassified & Unclassified & Unclassified \\
\hline
\end{tabular}

NSN 7540-01-280-5500

15. NUMBER OF PAGES

16. PRICE CODE 20. LIMITATION OF ABSTRACT

Standard Form 298 (Rev. 2-89)

Prescribed by ANSI Std. Z39-18 298-102 

